\title{
Does occupational exposure to dust prevent colorectal cancer?
}

\author{
Murray M Finkelstein
}

Health and Safety Studies Unit, Ontario Ministry of Labour, Toronto, Ontario, Canada

M M Finkelstein

Correspondence to: Dr Murray Finkelstein, Health and Safety Studies Unit, Ontario Ministry of Labour, 400 University Avenue, 7th Floor, Toronto, Ontario, Canada M7A 1T7.

Accepted 28 October 1994

\begin{abstract}
Objectives-To explore the impression that occupational epidemiologists tend to focus on associations suggestive of increased risk and tend to ignore those associations in which risk is not increased. To examine the risk of colorectal cancer in cohorts exposed to dust, cohorts in which it has been suggested that occupational exposure is a cause of increased risk of stomach cancer.
\end{abstract}

Methods-A review of the publications in the English language on mortality among hard rock miners, granite, and quarry workers identified from a MEDLINE search and the index of the library of the Ontario Ministry of Labour.

Results-When all of the studies were combined, there were significant excesses of lung and stomach cancers, but a significant deficit of colorectal cancer (standardised mortality ratio $(S M R)=83.9$; $95 \%$ confidence interval ( $95 \%$ CI) $76-91)$. Overall mortality from gastrointestinal cancer was close to expectation (SMR = 105; 95\% CI 99-111). Among those cohorts with increased risk of stomach cancer, rates of colorectal cancer were significantly decreased $($ SMR $=80 ; 95 \%$ CI 72-88). Among cohorts without increased risk of stomach cancer, the SMR for colorectal cancer was not significantly different from $100($ SMR $=98$; 95\% CI 81-115).

Conclusions-This review supports the impression that occupational epidemiologists tend to focus on associations suggestive of increased risk and tend to ignore those associations in which risk is not increased. The explanation for the inverse association between risk of stomach and colorectal cancer is uncertain and deserves further study.

(Occup Environ Med 1995;52:145-149)

often been associated with an increased risk of lung cancer and many epidemiologists have also found an increased risk of stomach cancer among these workers. ${ }^{13}$ Recently, the findings were published of an investigation of increased risk of stomach cancer among gold miners from Ontario. ${ }^{4}$ It was concluded that the excess of gastric cancer in gold miners may be the result of exposure to dust and that chromium may then be the causative agent, or closely associated with it. On reading the report of the original Ontario miners cohort study $^{5}$ I was struck by the finding that, even though mortality from stomach cancer was increased among the gold miners (60 deaths observed, 40 expected), overall mortality from digestive system cancer was less than expected (130 observed, 155 expected). This was attributable to a substantial deficit of colorectal cancers (28 observed, 65 expected). If occupational exposure to dust causes stomach cancer, could it also prevent cancer of the colon and rectum? The review of the medical literature presented here was conducted to investigate occupational associations with cancers of the intestinal tract (stomach, colon, rectum) in hard rock miners and quarry and granite workers.

\section{Methods}

Papers published in the English language on mortality among hard rock miners and granite and quarry workers were identified from a MEDLINE search of the literature from 1966 to 1994 . Government reports and conference proceedings in the library collection of the Ontario Ministry of Labour provided additional data.

The significance of differences between observed and expected mortality, and 95\% confidence intervals (95\% CIs) were assessed with the Poisson distribution or $\chi^{2}$ tests.

\section{Results}

STUDIES INCLUDED IN THE REVIEW

Keywords: epidemiology; stomach cancer; colorectal cancer

Perusal of publications on occupational medicine suggests that epidemiologists are excited by findings that imply that an occupational exposure increases the risk of a particular disease, but that, with the exception of the healthy worker effect, they tend to pay little attention to findings of decreased risk of disease in a workforce. Work in dusty trades has
Table 1 shows the studies included in this overview. They have been divided into categories representing mining of various ore types, granite and quarry workers, and the Vienna study of workers in dusty trades.

\section{Miners}

Gold miners-Simonato et al conducted a historical cohort mortality study of employees of a French gold mining and refining company to investigate the relation between lung cancer, 
Table 1 Mortality from lung and gastrointestinal cancer in cohorts exposed to dust

\begin{tabular}{|c|c|c|c|c|c|c|c|c|c|}
\hline \multirow[b]{2}{*}{ Cohort } & \multicolumn{3}{|l|}{ Lung } & \multicolumn{3}{|c|}{ Stomach } & \multicolumn{3}{|c|}{ Colon } \\
\hline & Obs & $\operatorname{Exp}$ & $S M R$ & Obs & $\operatorname{Exp}$ & $S M R$ & Obs & $\operatorname{Exp}$ & $S M R$ \\
\hline \multicolumn{10}{|l|}{ Gold: } \\
\hline Muller $e t a l^{5}$ & 196 & 135 & 145 & 60 & $40 \cdot 4$ & 148 & - & - & - \\
\hline Brown et al $^{7}$ & 43 & $42 \cdot 9$ & 100 & 10 & $12 \cdot 6$ & 79 & 10 & $12 \cdot 6$ & 79 \\
\hline Armstrong et $\mathrm{al}^{8}$ & 59 & $40 \cdot 8$ & 140 & 4 & $9 \cdot 8$ & 40 & - & - & - \\
\hline \multicolumn{10}{|l|}{ Uranium: } \\
\hline Muller $e t a l^{5}$ & 119 & 66 & 181 & 21 & 16 & 130 & - & - & - \\
\hline Nair et al (Beaverlodge) ${ }^{10}$ & 112 & $60 \cdot 9$ & 184 & 18 & $17 \cdot 9$ & 101 & 18 & $18 \cdot \overline{3}$ & 99 \\
\hline Waxweiller et al ${ }^{11}$ & 185 & 38 & 482 & 9 & 6 & 150 & 7 & $10 \cdot 2$ & 69 \\
\hline Morrison et al (Fluorspar) ${ }^{24}$ & 113 & $21 \cdot 5$ & 525 & 22 & $16 \cdot 2$ & 135 & 5 & $8 \cdot 7$ & 76 \\
\hline \multicolumn{10}{|l|}{ Iron: } \\
\hline Kinlen and Willows ${ }^{15}$ & 12 & $18 \cdot 3$ & 66 & 49 & $29 \cdot 5$ & 124 & 25 & $21 \cdot 1$ & 119 \\
\hline Lawler et al ${ }^{15}$ & 212 & 226 & 88 & 126 & $73 \cdot 1$ & 172 & 63 & 85.9 & 73 \\
\hline \multirow{2}{*}{\multicolumn{10}{|c|}{ Nickel or copper: }} \\
\hline & & & & & & & & & \\
\hline Muller et $a^{5}$ & 83 & 96 & 87 & 27 & 25 & 108 & - & - & - \\
\hline \multicolumn{10}{|l|}{ Other ore: } \\
\hline Muller et al & 5 & 3.83 & 131 & 1 & $1 \cdot 29$ & 77 & - & - & - \\
\hline Carta et al ${ }^{23}$ & 24 & $21 \cdot 5$ & 112 & 5 & 5 & 99 & - & - & 一 \\
\hline \multicolumn{10}{|l|}{ Mixed ore: } \\
\hline Muller $e t a l^{5}$ & 101 & $69 \cdot 5$ & 145 & 22 & $20 \cdot 8$ & 106 & - & - & - \\
\hline \multicolumn{10}{|l|}{ Tin: } \\
\hline Fox et al ${ }^{19}$ & 61 & 52 & 117 & 33 & $23 \cdot 4$ & 141 & - & - & - \\
\hline Chen et al ${ }^{17}$ & - & - & 198 & - & - & 60 & - & - & - \\
\hline \multicolumn{10}{|l|}{ Granite: } \\
\hline Koskela et $a l^{25}$ & 31 & $19 \cdot 9$ & 156 & 9 & $7 \cdot 1$ & 127 & - & - & - \\
\hline Mehnart et $a l^{26}$ & 27 & $24 \cdot 7$ & 109 & 13 & $11 \cdot 2$ & 116 & 3 & 3.8 & 80 \\
\hline Steenland and Beaumont ${ }^{27}$ & 97 & $81 \cdot 1$ & 119 & 29 & 29 & 0.99 & 37 & $33 \cdot 6$ & 110 \\
\hline \multicolumn{10}{|l|}{ Dusty trades: } \\
\hline Neuberger and Kundi ${ }^{3}$ & 179 & 106 & 169 & 77 & $46 \cdot 4$ & 166 & - & - & - \\
\hline Total & 1808 & 1202 & 150 & 564 & $422 \cdot 3$ & 134 & 175 & 205.9 & 85 \\
\hline
\end{tabular}

ICD = International classification of diseases

mortality, and exposure to arsenic, radon, silica, and other contaminants of the working environment. ${ }^{6}$ Muller and colleagues initiated, and are continuing, the Ontario miners study, a retrospective cohort mortality study of miners who worked in gold mines, nickel and copper mines, uranium mines, or mines for other ores. ${ }^{5}$ Brown et al reported a retrospective cohort mortality study of 3328 United States gold miners who had worked full time underground for at least one year between 1940 and $1965 .^{7}$ The reason for initiating that study was the hypothesis that exposure to amphibole mineral fibres found in the ore of the mine would be associated with diseases related to asbestos, such as lung cancer and asbestosis. Armstrong et al studied a cohort of Australian gold miners to test the hypothesis that there was an increased incidence of lung cancer attributable to their mining experience. ${ }^{8}$ Another study, not shown, is that of Wyndham and associates who studied a cohort of South African gold miners. ${ }^{9}$ They reported an increased risk of lung and stomach cancers, but make no mention of any other kinds of malignancies. It is thus not possible to comment on colorectal cancers in this cohort.

Uranium miners-Uranium miners are known to be at increased risk of lung cancer, attributable to exposure to radioactive radon daughters in the mines. Nair and colleagues reported on the mortality experience of employees of Eldorado Resources employed at the Port Radium and Beaverlodge uranium mines. ${ }^{10}$ Waxweiller et al studied the mortality experience of American uranium miners on the Colorado plateau. ${ }^{11}$ There is no mention of gastrointestinal cancers in the published reports of the New Mexican ${ }^{12}$ or Czech $^{13}$ uranium miners. It is thus not possible to comment on colorectal cancers in these cohorts.

Nickel and copper miners-Chen et al reported on the mortality experience of Chinese copper miners. ${ }^{14}$ Mortality from lung, stomach, oesophagus, and liver cancers was increased. There was no specific mention of colorectal cancers, but from the data presented, one may infer that mortality from colorectal cancers was probably less than expected.

Iron miners-Kinlen and Willows studied the mortality of 1947 English iron ore miners ${ }^{15}$ and Lawler and colleagues performed a cohort mortality study of 10403 Minnesota iron ore miners. ${ }^{16}$ Chen and colleagues studied the risk of mortality of iron ore miners in two mines in China. ${ }^{17}$ There was an increased risk of lung cancer, but mortality from stomach cancer was less than expected. There was

Table 2 Lung and colorectal cancers in cohorts with and without increased mortality from stomach cancer

\begin{tabular}{|c|c|c|c|c|c|c|c|c|c|}
\hline & \multicolumn{3}{|l|}{ Lung } & \multicolumn{3}{|c|}{ Stomach } & \multicolumn{3}{|c|}{ Colon } \\
\hline & $O b s$ & $\operatorname{Exp}$ & $S M R$ & Obs & $\operatorname{Exp}$ & $S M R$ & Obs & $\operatorname{Exp}$ & $S M R$ \\
\hline \multirow{2}{*}{$\begin{array}{l}\text { Cohorts with increased } \\
\text { mortality from stomach cancer } \\
\text { Cohorts without increased } \\
\text { mortality from stomach cancer }\end{array}$} & 1319 & 873 & 151 & 468 & 315 & 149 & 103 & 130 & 79 \\
\hline & 484 & 322 & 150 & 95 & 105 & 90 & 72 & 76 & 94 \\
\hline
\end{tabular}




\begin{tabular}{|c|c|c|c|c|c|c|c|c|}
\hline \multicolumn{3}{|c|}{ Rectum } & \multicolumn{3}{|c|}{ Colorectal } & \multicolumn{3}{|c|}{$\begin{array}{l}\text { Gastrointestinal } \\
\text { (ICD:151-154) }\end{array}$} \\
\hline Obs & $\operatorname{Exp}$ & $S M R$ & Obs & $\operatorname{Exp}$ & $S M R$ & Obs & $\operatorname{Exp}$ & $S M R$ \\
\hline $\begin{array}{r}{ }^{1} \\
-^{6}\end{array}$ & $-^{1.4}$ & $\begin{array}{l}70 \\
\overline{120} \\
-\end{array}$ & $\begin{array}{r}1 \\
28 \\
16 \\
9\end{array}$ & $\begin{array}{l}3 \cdot 89 \\
65 \cdot 4 \\
17 \cdot 6 \\
11\end{array}$ & $\begin{array}{l}26 \\
43 \\
91 \\
80\end{array}$ & $\begin{array}{r}4 \\
88 \\
26 \\
13\end{array}$ & $\begin{array}{r}6 \cdot 5 \\
105 \cdot 8 \\
30 \cdot 2 \\
20 \cdot 8\end{array}$ & $\begin{array}{l}62 \\
83 \\
86 \\
63\end{array}$ \\
\hline $\begin{array}{r}- \\
2 \\
8 \\
1 \\
2\end{array}$ & $\begin{array}{r}- \\
\\
4 \cdot 3 \\
8 \cdot 4 \\
3 \cdot 7 \\
4 \cdot 3\end{array}$ & $\begin{array}{l}-47 \\
95 \\
27 \\
47\end{array}$ & $\begin{array}{r}23 \\
9 \\
26 \\
8 \\
9\end{array}$ & $\begin{array}{l}28 \cdot 7 \\
13.5 \\
26 \cdot 7 \\
13.9 \\
13.5\end{array}$ & $\begin{array}{l}80 \\
67 \\
99 \\
58 \\
67\end{array}$ & $\begin{array}{l}44 \\
16 \\
44 \\
17 \\
31\end{array}$ & $\begin{array}{l}44 \cdot 7 \\
22 \cdot 9 \\
44 \cdot 6 \\
19 \cdot 9 \\
29 \cdot 7\end{array}$ & $\begin{array}{r}98 \\
70 \\
99 \\
85 \\
104\end{array}$ \\
\hline $\begin{array}{r}23 \\
45 \\
-\end{array}$ & $\begin{array}{l}17 \\
37 \\
-\end{array}$ & $\begin{array}{l}134 \\
123 \\
-\end{array}$ & $\begin{array}{r}48 \\
108 \\
2\end{array}$ & $\begin{array}{c}38 \cdot 1 \\
112 \cdot 4 \\
1 \cdot 15\end{array}$ & $\begin{array}{r}126 \\
96 \\
174\end{array}$ & $\begin{array}{r}97 \\
234 \\
2\end{array}$ & $\begin{array}{c}67 \cdot 6 \\
185 \cdot 5 \\
1 \cdot 81\end{array}$ & $\begin{array}{l}144 \\
126 \\
110\end{array}$ \\
\hline- & - & - & 35 & $42 \cdot 6$ & 82 & 62 & $67 \cdot 6$ & 92 \\
\hline E & E & E & $\begin{array}{r}0 \\
14 \\
4\end{array}$ & $\begin{array}{l}2 \cdot 13 \\
7 \cdot 6 \\
3 \cdot 9\end{array}$ & $\begin{array}{r}0 \\
183 \\
102\end{array}$ & $\begin{array}{r}1 \\
33 \\
9\end{array}$ & $\begin{array}{c}3 \cdot 42 \\
26 \cdot 5 \\
8 \cdot 9\end{array}$ & $\begin{array}{r}29 \\
124 \\
101\end{array}$ \\
\hline- & - & - & 23 & $34 \cdot 2$ & 69 & 45 & 55 & 82 \\
\hline - & - & - & $\begin{array}{l}21 \\
68\end{array}$ & $\stackrel{3}{ }^{37 \cdot 8}$ & $\begin{array}{l}56 \\
68\end{array}$ & $-^{54}$ & $\underbrace{61 \cdot 2}$ & $\stackrel{88}{-}^{-}$ \\
\hline $\begin{array}{l}-12 \\
13\end{array}$ & $\begin{array}{c}- \\
14 \cdot 6\end{array}$ & $\begin{array}{r}\overline{263} \\
90\end{array}$ & $\begin{array}{r}0 \\
15 \\
50\end{array}$ & $\begin{array}{l}3 \\
8 \cdot 33 \\
48\end{array}$ & $\begin{array}{r}0 \\
180 \\
104\end{array}$ & $\begin{array}{r}9 \\
28 \\
79\end{array}$ & $\begin{array}{l}10 \cdot 1 \\
19 \cdot 53 \\
77\end{array}$ & $\begin{array}{r}89 \\
143 \\
103\end{array}$ \\
\hline$\overline{113}$ & $\overline{100}$ & $\overline{113}$ & $\begin{array}{r}34 \\
483\end{array}$ & $\begin{array}{c}42 \\
575 \cdot 4\end{array}$ & $\begin{array}{l}81 \\
84\end{array}$ & $\begin{array}{r}111 \\
1047\end{array}$ & $\begin{array}{r}88 \cdot 4 \\
997 \cdot 7\end{array}$ & $\begin{array}{l}126 \\
105\end{array}$ \\
\hline
\end{tabular}

no mention of mortality from colorectal cancer. Pham et al reported on the mortality of French iron miners. ${ }^{18}$ There was an increased risk of lung, stomach, bladder, and prostate cancers. Colorectal cancer was not specifically mentioned, but because mortality from cancers other than those mentioned earlier was less than expected, mortality from colorectal cancer was presumably also less than expected.

Tin miners-Fox and colleagues studied Cornish tin miners to investigate mortality among men exposed to high levels of radon in underground air ${ }^{19}$ and Chen et al studied mortality among 68000 people employed during 1972-4 at metal mines and pottery factories in China. ${ }^{20}$ Hodgson and Jones studied the mortality patterns of United Kingdom tin miners with particular attention to lung cancer and exposure to radon. ${ }^{21}$ They reported increased risk of lung and stomach cancers, but make no mention of colorectal cancers. It is thus not possible to comment on colorectal cancers in this cohort.

Other ores-Battista and colleagues performed a cohort mortality study of miners in Central Italy to evaluate the effects of exposure to radon, ${ }^{22}$ and Carta et al studied a group of Sardinian metal miners with low level exposure to radon. ${ }^{23}$ Morrison et al inves-

\begin{tabular}{|c|c|c|c|c|c|c|c|c|}
\hline \multicolumn{3}{|c|}{ Rectum } & \multicolumn{3}{|c|}{ Colorectal } & \multicolumn{3}{|c|}{$\begin{array}{l}\text { Gastrointestinal } \\
\text { (ICD:151-154) }\end{array}$} \\
\hline Obs & Exp & $S M R$ & Obs & $\operatorname{Exp}$ & $S M R$ & Obs & $\operatorname{Exp}$ & $S M R$ \\
\hline 83 & 66 & 125 & 352 & 440 & 80 & 820 & 755 & 108 \\
\hline 30 & 33 & 90 & 129 & 132 & 98 & 224 & 237 & 94 \\
\hline
\end{tabular}

tigated a cohort of Newfoundland miners exposed to radon while mining fluorspar. ${ }^{24}$

\section{Granite and quarry workers}

Koskela and colleagues undertook a mortality study of 1026 Finnish granite workers employed in quarries and processing yards..$^{25}$ There was an increased risk of lung and stomach cancers, but no colorectal cancers were observed (expected about three). Mehnert et al studied mortality in a cohort of German slate quarry workers. ${ }^{26}$ Steenland and Beaumont studied death benefit records of 1905 members of the Granite Cutters Union. ${ }^{27}$ Proportionate mortality from lung cancer was increased. Mortality from stomach and colorectal cancer were both similar to expectation. Davis and colleagues studied the mortality pattern of 969 deceased Vermont granite workers. ${ }^{28}$ Mortality from lung cancer was increased. Mortality from cancer of the digestive organs was slightly increased, but the authors provided no breakdown by location in the digestive tract.

\section{Dusty trades workers}

During the period 1950 to 1960 , occupational and smoking histories were collected in the course of preventive medical examinations of 247064 workers in Vienna. Of these, 1630 workers aged $\geqslant 40$ years were selected because of their occupational exposure to silica and "inert" dusts, and were matched to 1630 subjects without such exposure. Follow up to the end of 1985 found increased mortality from lung and stomach cancer, but decreased colorectal mortality among the subjects exposed to dust. ${ }^{3}$ This paper is included here because the focus of interest of the researchers was risk of lung and stomach cancer in workers exposed to dust.

\section{SUMMARY OF RESULTS}

The summary line in table 1 shows that when all of the studies are combined, there are significant excesses of lung cancer (SMR 150) and stomach cancer $(\mathrm{SMR}=133 ; 95 \% \mathrm{CI}$ 123-145), but a significant deficit of colorectal cancer (SMR $=84 ; 95 \%$ CI 76-91). Combining those studies that presented details for colonic and rectal cancers separately, there was a deficit of colonic cancer $(S M R=85 ; 95 \%$ CI 72-98) and an excess of rectal cancer $(S M R=113 ; 95 \%$ CI 92-134). Overall mortality from gastrointestinal cancer was close to expectation (SMR $=105 ; 95 \%$ CI 99-111).

Table 2 shows the data on the question of whether or not risk of colorectal cancer varies with risk of stomach cancer. Where there is an increased risk of stomach cancer (Obs/Exp > 1) rates of lung and stomach cancer are both significantly increased and rates of colorectal cancer are significantly decreased $(S M R=80$; 95\% CI 72-88). Where there is no increased risk of stomach cancer (Obs/Exp < 1) risk of lung cancer is again increased, the stomach cancer SMR is 90 and the colorectal cancer SMR is 98 (95\% CI 81-115), not significantly different from 100 . 


\section{Discussion}

This literature review was conducted to explore the hypothesis that occupational epidemiologists focus on positive associations and tend to ignore associations suggestive of a protective effect. Having noticed an inverse association between stomach and colorectal cancers in one cohort exposed to dust I reviewed the medical literature to find whether this was a more general finding. Is there an inverse relation between the mortalities from stomach and colorectal cancer such that the overall gastrointestinal mortality is close to expectation in cohorts exposed to dust?

In a review such as this, one has always to be concerned about bias-namely, publication bias in determining which studies are submitted and accepted for publication and selection bias in retrieving papers for review. Papers for this review were selected from a search of MEDLINE for papers in the English language on mining and quarrying, supplemented by a search of the Ministry of Labour occupational medicine database. In most of these papers the main sites of interest were lung and stomach cancers. There is thus unlikely to be any bias with respect to publication of studies with increased or decreased risk of colorectal cancer. The hypothesis that authors are primarily interested in positive findings is supported by the finding that because of the concern with lung and stomach cancers (positive sites), results for these sites were almost always presented whereas results for colorectal cancers were often omitted from the published papers.

It was found that when mortalities from stomach cancer were increased, mortalities from colorectal cancer tended to be decreased, and when mortalities from stomach cancer were not increased mortalities from colorectal cancer were similar to the expected (table 2). How might these findings be explained? The simplest explanation is that neither the increased risk of stomach cancer nor the decreased risk of colorectal cancer are caused by occupational exposures. Inappropriate reference populations have been chosen for these cohorts exposed to dust and the results for the risks of stomach and colorectal cancer are both due to confounding. The observations in table 2 would tend to support this interpretation because in those studies in which the SMR for one site was close to expectation, so was the SMR for the other site. When the SMR for one site was significantly different from expectation, so was the SMR for the other site.

The causes of colon cancer are poorly known. A recent review of the literature ${ }^{29}$ reported that evidence from migration studies and international comparisons suggested a strong environmental component to the aetiology. Most recent studies have focused on the importance of nutritional factors. Several occupational studies have been conducted. ${ }^{30} 31$ Associations of colorectal cancer with occupation have generally been weak and the statistical power to identify associations has been low. The main consistent finding has been the protective effect of physical exertion. Odds ratios have been in the range of 0.5 to 0.8 for active occupations in comparison to sedentary ones. ${ }^{29}$ It has been hypothesised that physical activity stimulates peristalsis, decreasing colonic transit time and exposure to intralumenal carcinogens.

The next explanation for the association between dust exposure and risk of gastrointestinal cancer summarised in table 2 is that risk is causally related to occupation, and the same work factor caused both the increase in risk of stomach cancer and the decrease in risk of colon cancer. One might thus speculate that physical activity increases the risk of stomach cancer and decreases the risk of colon cancer, or that substances in ingested dust increase the risk of stomach cancer and that they, or modified daughters, then pass down the intestinal tract to decrease the risk of colon cancer.

The next logical combination is that separate aspects of workplace exposure are involved in modification of risk at different places in the gastrointestinal tract. Perhaps ingested dust increases the risk of stomach cancer whereas physical exertion decreases the risk of colon cancer. It is not possible to sort out all these alternatives at present, but these issues seem to be worthy of further investigation.

\section{Conclusions}

This review supports the impression that occupational epidemiologists tend to focus on associations suggestive of increased risk and tend to ignore those associations in which risk is not increased. We have found that in cohorts exposed to dust in which the risk of stomach cancer is increased, there is a concomitant decrease in the risk of colorectal cancer such that the overall risk of gastrointestinal cancer is similar to expectation. The explanation for the inverse association between the risks of stomach and colorectal cancer is uncertain and deserves further study.

1 Bross ID, Viadana E, Houten L. Occupational cancer in men exposed to dust and other environmental hazards. Arch Environ Health 1978;33:300-7.

2 Wright WE, Bernstein L, Peters JM, Garabrant D, Mack TM. Adenocarcinoma of the stomach and exposure to occupational dust. Am $\mathscr{F}$ Epidemiol 1988;128:64-73.

3 Neuberger M, Kundi M. Occupational dust exposure and cancer mortality-results of a prospective cohort study. In: Simonato L, Fletcher AC, Saracci R, et al, eds Occupational exposure to silica and cancer risk. Lyon IARC, 1990.

4 Kusiak RA, Ritchie AC, Springer J, Muller J. Mortality from stomach cancer in Ontario miners. Br f Ind Med 1993;50:117-26.

5 Muller J, Wheeler WC, Gentleman JF, Kusiak RA, Suranyi G. Study of mortality of Ontario miners 1955-1977: part I. Toronto: Ontario Ministry of Labour, 1983.

6 Simonato L, Moulin J, Javelaud B, Ferro G, Wild P, Winklemann R, Saracci R. Retrospective mortality study of workers exposed to arsenic in a gold mine and refinery of workers exposed to arsenic in a gold min

7 Brown DP, Kaplan SD, Zumwalde RD, Kaplowitz M Archer VE. Retrospective cohort mortality study of urcher VE. Retrospective cohort mortality study of Winn DM, Shy CM, eds. Silica, silicosis, and cancer. New York: Praeger, 1986:335-49. 
8 Armstrong BK, McNulty JC, Levitt LJ, Williams KA, Hobbs MST. Mortality in gold and coal miners in Western Australia with special reference to lung cancer. Br F Ind Med 1979;36:199-205.

9 Wyndham CH, Bezuidenhout BN, Greenacre MJ, Sluis-Cremer GK. Mortality of middle aged South African gold miners. Br $\mathcal{F}$ Ind Med 1986;43:677-84.

10 Nair RC, Abbatt JD, Howe GR, Newcombe HB, Frost SE. Mortality experience among workers in the Uranium industry. In: Stocker $\mathrm{H}$, ed. Occupational radiation safety in industry. In: Stocker $\mathrm{H}$, ed. Occupational radiation safety in
mining. Proceedings of the International Conference. mining. Proceedings of the International Conf

11 Waxweiller RJ, Roscoe RJ, Archer VE. Mortality follow-up through 1977 of the white underground uranium miners cohort examined by the United States Public miners cohort examined by the United States Public
Health Service. In: Gomez $\mathrm{M}$, ed. Radiation hazards Health Service. In: Gomez $\mathrm{M}$, ed. Radiation hazards
in mining: control, measurement, and medical aspects. New York: Society of Mining Engineers, 1981: 823-30.

12 Samet JM, Pathak DR, Morgan MV, Key CR, Valdivia $\mathrm{AA}$, Lubin JH. Lung cancer mortality and exposure to radon progeny in a cohort of New Mexico underground uranium miners. Health Phys 1991;61:745-52.

13 Sevc J, Tomasek L, Kunz E, Placek V, Chmelevsky D, Barclay D. A survey of the Czechoslovak follow-up of cancer mortality in uranium miners. Health Phys 1993; 64:355-69.

14 Chen R, Wei L, Huang H. Mortality from lung cancer among copper miners. Br 7 Ind Med 1993;50: cancer

15 Kinlen LJ, Willows AN. Decline in the lung cancer hazard: a prospective study of the mortality of iron ore miners in Cumbria. Br F Ind Med 1988;45:219-24.

16 Lawler AB, Mandel JS, Schumann LM, Lubin JH. A retrospective cohort mortality study of iron ore (hematite) miners in Minnesota. F Occup Med 1985;27:507-17.

17 Chen SY, Hayes RB, Liang SR, Li QG, Stewart PA, Blair A. Mortality experience of haematite mine workers in China. Br F Ind Med 1990;47:175-81.

18 Pham OT, Caillier I, Chau N, Teculescu D, Patris A, Trombert B. La mortalite des mineurs de fer du Bassin de Lorraine. Arch Mal Prof 1993;54:391-6.
19 Fox AJ, Goldblatt P, Kinlen LJ. A study of the mortality of Cornish tin miners. Br $\mathcal{F}$ Ind Med 1981;38:378-80.

20 Chen J, McLaughlin JK, Zhang J, Stone BJ, Luo J, Chen $R$. Mortality among dust-exposed Chinese mine and pottery workers. $\mathcal{F}$ Occup Med 1992;34:311-6.

21 Hodgson JT, Jones RD. Mortality of a cohort of tin miners 1941-86. Br F Ind Med 1990;47:665-76.

22 Battista G, Belli S, Carboncini F, Comba P, Levante G, Sartorelli P. Mortality among pyrite miners with lowlevel exposure to radon daughters. Scand $\mathcal{F}$ Work Environ Health 1988;14:280-5.

23 Carta P, Cocco P, Picchiri G. Lung cancer mortality and airways obstruction among metal miners exposed to silica
and low levels of radon daughters. Am $\mathcal{f}$ Ind Med and low levels of

24 Morrison HI, Semenciw RM, Mao Y, Wigle DT. Cancer mortality among a group of fluorspar miners exposed to radon progeny. Am $\mathcal{F}$ Epidemiol 1988;128:1266-75.

25 Koskela RS, Klockars M, Jarvinen E, Kolari P, Rossi A. Cancer mortality of granite workers 1940-1985. In: Simonato L, Fletcher AC, Saracci R, eds. Occupational exposure to silica and cancer risk. Lyon: IARC, 1990. (IARC Sci Publ No 97.)

26 Mehnert WH, Stanaczek W, Mohner M, Konetzke G, Muller W, Ahlendorf W. A mortality study of slate quarry workers in the German Democratic Republic. In: Simonato L, Fletcher AC, Saracci R, eds. Occupational Simonato L, Fletcher AC, Saracci R, eds. Occupational
exposure to silica and cancer risk. Lyon: IARC, 1990. exposure to silica and cance
(IARC Sci Publ No 97.)

27 Steenland K, Beaumont J. A proportionate mortality study of granite cutters. Am f Ind Med 1986;9:189-201.

28 Davis LK, Wegman D, Monson RR, Froines J. Mortality experience of Vermont granite cutters. Am $\mathcal{F}$ Ind Med 1983;4:705-23.

29 Potter JD, Slattery ML, Bostick RM, Gapstur SM. Colon cancer: a review of the epidemiology. Epidemiol Rev 1993;15:499-545.

30 Spiegelman D, Wegman $\mathrm{DH}$. Occupation-related risks for colorectal cancer. $\mathcal{F}$ Natl Cancer Inst 1985;75:813-21.

31 Brownson RC, Zahm SH, Chang JC. Occupational risk of colon cancer: an analysis by anatomic subsite. $A m \mathcal{F}$ Colon cancer: an analysis by

\section{Vancouver style}

All manuscripts submitted to Occup Environ Med should conform to the uniform requirements for manuscripts submitted to biomedical journals (known as the Vancouver style.)

Occup Environ Med, together with many other international biomedical journals, has agreed to accept articles prepared in accordance with the Vancouver style. The style (described in full in the $B M F, 24$ February $1979, p$ 532) is intended to standardise requirements for authors.

References should be numbered consecutively in the order in which they are first mentioned in the text by Arabic numerals above the line on each occasion the reference is cited (Manson ${ }^{1}$ confirmed other reports $^{2-5}$. . .). In future references to papers submitted to Occup Environ Med should include: the names of all authors if there are seven or less or, if there are more, the first six followed by et al; the title of journal articles or book chapters; the titles of journals abbreviated according to the style of Index Medicus; and the first and final page numbers of the article or chapter. Titles not in Index Medicus should be given in full.

Examples of common forms of references are:

1 International Steering Committee of Medical Editors, Uniform requirements for manuscripts submitted to biomedical journals. Br Med f 1979;1:532-5.

2 Soter NA, Wasserman SI, Austen KF. Cold urticaria: release into the circulation of histamine and eosinophil chemotactic factor of anaphylaxis during cold challenge. N Engl f Med 1976;294:687-90.

3 Weinstein L, Swartz MN. Pathogenic properties of invading micro-organisms. In: Sodeman WA Jr, Sodeman WA, eds. Pathologic physiology, mechanisms of disease. Philadelphia: W B Saunders, 1974:457-72. 